\title{
HUMOR JUI PUR WOTO, CAK LONTONG, PANDJI PRAGIWAKSONO, DAN ERNEST PRAKAS DALAM STAND UP COMEDY (ANALISIS MAKNA KONTEKSTUAL, MAKNA KONSEPTUAL, DAN TEORI HUMOR DALAM KALIMAT HUMOR)
}

\author{
Aan Sugiantomas, Asep Jejen Jaelani, \& Ayya Natashya Supriatna \\ Pedidikan Bahasa dan Sastra Indonesia Universitas Kuningan \\ Jalan Cut Nyak Dien no. 36 A Kuningan Jawa Barat
}

\begin{abstract}
Abstrak
Judul penelitian ini adalah Humor Jui Purwoto, Cak Lontong, Pandji Pragiwaksono dan Ernest Prakasa Dalam Stand Up Comedy.Rumusan Masalah: 1)bagaimana kalimat humor Jui Purwoto pada penampilannya di stand up comedy? 2) bagaimana makna kontekstual, makna konseptual dan teori humor dalam kalimat humor Jui Purwoto pada penampilannya di stand up comedy? 3) bagaimana kalimat humor Cak Lontong pada penampilannya di stand up comedy? 4) bagaimana makna kontekstual, makna konseptual dan teori humor dalam kalimat humor Cak Lontong pada penampilannya di stand up comedy? 5) bagaimana kalimat humor Pandji Pragiwaksono pada penampilannya di stand up comedy? 6) bagaimana makna kontekstual, makna konseptual dan teori humor dalam kalimat humor Pandji Pragiwaksono pada penampilannya di stand up comedy? 7) bagaimana kalimat humor Ernest Prakasa pada penampilannya di stand up comedy? 8) bagaimana makna kontekstual, makna konseptual dan teori humor dalam kalimat humor Ernest Prakasa pada penampilannya di stand up comedy? Tujuan penelitian: 1) ingin mengetahui kalimat humor Jui Purwoto pada penampilannya di stand up comedy; 2) ingin mengetahui makna kontekstual, makna konseptualdan teori humor dalam kalimat humor yang digunakan Jui Purwoto pada penampilannya di stand up comedy; 3) ingin mengetahui kalimat humor Cak Lontong pada penampilannya di stand up comedy; 4) ingin mengetahui makna kontekstual, makna konspetual dan teori humor dalam kalimat humor Cak Lontong pada penampilannya di stand up comedy; 5) ingin mengetahui kalimat humor Pandji Pragiwaksono pada penampilannya di stand up comedy; 6) Ingin mengetahui makna kontekstual, makna konseptual dan teori humor dalam kalimat humor Pandji Pragiwaksono pada penampilannya di stand up comedy; 7) Ingin mengetahui kalimat humor Ernest Prakasa pada penampilannya di stand up comedy; 8) Ingin mengetahui makna kontekstual, makna konseptual dan teori humor dalam kalimat humor Ernest Prakasa pada penampilannya di stand up comedy. Metode: deskriftif analitik. Simpulan: 1) kalimat humor Jui Purwoto pada penampilannya di stand up comedy terdapat pada monolog humornya. Yang telah dianalisis pada sudut pandang makna kontekstual, makna konseptual, dan teori humor. Dan menceritakan tentang kejadian pembunuhan gadis belia oleh mantan kekasihnya hingga ramainya tauran yang berawal dari tidak adanya kegiatan setalah pulang sekolah; 2)Makna kontekstual, makna konseptual dan teori humor dalam kalimat humor yang digunakan Jui Purwoto pada penampilannya di stand up comedy adalah kalimat humor yang dilihat pada makna kontekstual sangat berpengaruh terhadap situasi, kondisi, dan peristiwa dimana kalimat humor terucap. Pada kalimat humor Jui ini yang didalamnya tentang pembunuhan gadis belia oleh mantan kekasihnya sampai permasalahan tentang tauran yang sering terjadi. Kalimat humor Jui Purwo to yang dilihat pada makna konseptual ini tidak perlu adanya pengaruh diluar bahasa, situasi, kondisi, dan peristiwa. Tanpa mengetahui situasi, kondisi, dan peritiwa, kita dapat memahami makna yang terkandung, karena maknanya sudah terlihat pada konsep kalimatnya.Teori humor pada kalimat humor Jui Purwoto lebih banyak menggunakan teori ketidaksesuaian atau ketidakseimbangan. Selanjutnya teori kelegaan atau kebebasan, dan teori superioritas dan meremehkan; 3) kalimat humor Cak Lontong pada
\end{abstract}


penampilannya di stand up comedy terdapat pada monolog humornya yang menceritakan tentang miskin dan sederhana menurut Cak Lontong; 4) makna kontekstual, makna konseptual dan teori humor dalam kalimat humor Cak Lontong pada penampilannya di stand up comedy adalah kalimat humor yang dilihat ada makna kontekstual ini sangat dipengaruhi oleh situasi, kondisi, dan peristiwa pada saat kalimat humor diucapkan oleh Cak Lontong. Dan kalimat ini diucapkan pada saat Cak melakukan stand up comedyyang didalamnya menceritakan tentang miskin dan sederhana. Sedangkan pada kalimat humor Cak Lontong yang dilihat pada makna konseptual tidak ada pengaruhnya oleh situasi, kondisi, dan peristiwa. Sebagai pembaca tanpa mengetahui pengaruh luar kebahasaan tetap akan memahami makna kalimat tersebut sesuai konsep kalimatnya. Dan pada teori humor dalam kalimat humor Cak lontong yang lebih unggul digunakannya adalah teori ketidaksesuaia, atau ketidakseimbangan; 5) kalimat humor Pandji Pragiwaksono pada penampilannya di stand up comedy terdapat pada monolog humornya yang berisikan tentang Sea Games, dan kemenangan Indonesia dalam ajang Sea Games, serta adanya umpatan Pandji tentang Jakarta yang nyatanya terdapat kemunduruan; 6) makna kontekstual, makna konseptual dan teori humor dalam kalimat humor Pandji Pragiwaksono pada penampilannya di stand up comedy adalah kalimat yang dianalisis pada makna kontekstual sangat berpengaruh terhadap luar kebahasaan yakni situasi, kondisi, dan peristiwa diman akalimat tersebut diucapkan. Danpada kalimat humor Pandji yang diucapkan saat penampilannya berstand up comedy di depan penonton yang menceritakan kedalam bentuk humor. Dan pada makna konseptual kalimat dapat dipahami tanpa adanya pengaruh dari situasi, kondisi, dan peristiwa. Kalimat humor pada teori humor yang digunakan Pandji lebih unggul dengan teori kelegaan dan kebebasan karena dalam kalimat humornya banyak sindiran dan umpatan yang dikeluarkan Pnadji dengan cara berhumornya; 7) kalimat humor Ernesr Prakasa pada penampilannya di stand up comedy terdapat pada monolog humor Ernest Prakasa yang berisikan tentang cerita saat dirinya membeli televisi, dan kisah tentang pembantu rumah tangganya yang memliki bahasa yang aneh; 8) makna kontekstual, makna konseptual dan teori humor dalam kalimat humor Ernest Prakasa pada penampilannya di stand up comedy adalah kalimat humor yang dianalisis pada makna kontekstual sangat berpengaruh terhadap situasi, kondisi, dan peritiwa dimana kalimat humor tersebut di ucapkan oleh Ernest. Dan pada saat itu, kalimat diucapkan pada saat Ernest berstand up comedy yang menceritakan tentang pengalamannya membeli televisi dan menceritakan pula pembantunya yang memiliki keunikan dalam berbahasa. Sedangkan pada makna konseptual, hanya dilihat dari konsep kalimat humornya itu sendiri, dan maknanya tidak akan berpengaruh dari situasi, kondisi, dan peristiwa. Dan kalimat humor Ernest yang lebih unggul dalam teori humor yang digunakan adalah teori ketidaksesuaia atau ketidakseimbangan.

Kata kunci : makna kontekstual, makna konseptual, dan teori humor.

\section{PENDAHULUAN}

Humor merupakan sesuatu yang beridentik dengan segala yang lucu, yang membuat orang tertawa dan sifatnya menghibur seseorang.Humor memiliki beberapa kelompok, yakni dari kelompok teori superioritas atau meremehkan, teori ketidaksesuaian, dan teori kelegaan atau kebebasan (Setaiawan, 1990, dalam Rahamanadji 2009: 217).Tanpa kita sadari sebagai penikmat humor tidak semata-mata keluar dari dalam pikiran dan menjadikannya humor.Ternyata di dalam humor itu sendiri memiliki referensi ilmiah.Bukan hanya humor lelucon belaka. 
Humor tidak dihasilkan secara langsung dari manusia dengan ucapan, humor juga dapat dituangkan dari segala jenisnya. Menurut Arwah (dalam Rahmanadji, 2009: 218) humor dibagi kedalam tiga jenis, yakni (1) humor personal, yang kecenderungan tertawa sendiri pada diri kita dari suatu kejadian yang dilihat yang menurutnya lucu, (2) humor dalam pergaulan, yakni humor yang dilakukan saat kita bersenda gurau dengan teman, dan (3) humor dalam kesenian, yang ternyata di dalamnya masih terdapat beberapa bagian, yakni pertama dari humor lakuan, contohnya lawak, tari humor dan pantonim, yang kedua humor grafis, contohnya kartun, karikatur, patung, dan yang ketiga humor literature, contohnya cerpen lucu, sajak jenaka, yang berbentuk tulisan.

Pada humor lakuan, lawak termasuk kedalammya. Kita mendengarnya pun tidak akan asing. Karena lawak adalah suatu cerita nyata maupun fiksi yang sifatnya lucu atau jenaka.Dan seseorang yang memberikan lawak tersebut adalah pelawak. Jadi pelawak merupakan seseorang komedian yang menghibur penonton dalam membuat mereka tertawa, yakni dengan cara melawak. Sedangkan melawak adalah suatu tindakan yang dialakukan pelawak untuk membuat mereka tertawa dengan cerita yang telah dihasilkan. Di Indonesia contohnya, mendengar kata lawak, melawak, dan pelawak pasti tidak akan asing lagi, karena dari jaman kejamannya seseorang yang bergelut dalam humor tidak akan pernah pudar atau kurang peminatnya. Melalui pelawak kita akan merasakan kebahagian dari tertawa karena tingkah mereka. Pelawak yang biasanya dahulu dikenal dalam berkelompok, contohnya ketoprak, srimulat dan kelompok pelawak lainnya, ternyata seorang diri pun dapat dilakukannya untuk menghibur penonton.

Berstand up comedy merupakan salah satu humor yang menggunakan pikiran tanpa ada unsur menjelek-jelekan seseorang. Tetapi terkadang dalam humor stand up ada unsur menyindir, dari kondisi di Indonesia hingga sindiran ke politik seseorang yang berstand up comedy pasti memliki banyak cerita monolog yang telah dihasilkan. Dan mereka mempersiapkannya dengan matang pada saat akan tampil. Kalimat humor seorang stand up comedy tidak semata-mata dibuatnya, didalamnya ternyata memiliki referensi ilmiah dan dari kalimat humor yang akan disampaikan memiliki makna dengan tujuan tertentu. Seorang stand up comedy bisa mengutarakannya, dari kegelisahan hatinya mau pun kegelisahan negara ini tanpa harus berucap secara lugas, tetapi mengajak penonton untuk saling berpikir, bukan sekedar tertawa. Karena humor bukan sekedar lelucon belaka, dan juga bukan hanya perkara menikmatinya dengan tertawa saja.Ternyata humor memacu kita untuk lebih cerdas dan kreatif dalam menyikapinya.

Dengan demikian, penulis tertarik untuk menganalisis kalimat humor yang disampaikan para pembawa stand up comedy ditinjau dari teori humor yang terdapat dalam kalimat-kalimat humor monolognya dan makna yang terkandung dalam humornya. Karena penulis, sebagai peneliti membutuhkan jawaban yang ilmiah. Karena humor merupakan hiburan yang serius dan menuntut pemikiran dan kecerdasan dalam membuat orang lain tertawa atau terhibur.

Berdasarkan latar belakang masalah di atas, penulis merumuskan masalah (1)Bagaimana kalimat humor Jui Purwoto pada penampilannya di stand up comedy? (2) Bagaimana makna kontekstual, makna konseptual dan teori humor dalam kalimat humor Jui Purwoto pada penampilannya di stand up comedy? 3) Bagaimana kalimat humor Cak Lontong pada penampilannya di stand up comedy? (4) Bagaimana makna kontekstual, makna konseptual dan teori humor dalam kalimat humor Cak Lontong pada penampilannya di stand up comedy? (5) Bagaimana kalimat humor Pandji Pragiwaksono pada penampilannya di stand up comedy? (6) Bagaimana makna kontekstual, makna konseptual dan teori humor dalam kalimat humor Pandji Pragiwaksono pada penampilannya di stand up comedy? (7) Bagaimana kalimat humor Ernest Prakasa pada penampilannya di stand up comedy? (8) 
Bagaimana makna kontekstual, makna konseptual dan teori humor dalam kalimat humor Ernest Prakasa pada penampilannya di stand up comedy?

\section{TINJAUAN PUSTAKA}

\section{1) Humor}

\section{(1) Teori Humor}

Teori humor jumlahnya sangat banyak, tidak satupun yang persis sama dengan yang lainnya, tidak satu pun juga yang bisa mendeskripsikan humor secara menyeluruh, dan semua cenderung saling terpengaruh (Setiawan, 1990, dalam Rahmanadji 2009: 216).

Humor sesuatu yang lucu, yang memiliki rasa menurut KBBI.Sedangkan menurut Ensiklopedi Indonesia (dalam Ramanadji 2009:216) humor identik dengan segala sesuatu yang lucu, yang membuat orang tertawa.Humor itu kualitas untuk menghimbau rasa geli atau lucu, karena keganjilannya atau ketidakpantasannya yang menggelikan, paduan antara rasa kelucuan yang halus di dalam diri manusia dan kesadaran hidup yang iba dengan sikap sempatik (Setiawan, 1990, dalam Rahmanadji 2009: 216).Menurut Manser (dalam Rahmanadji, 2009:216) teori humor dibagi dalam tiga kelompok sebagai berikut.

a) Teori superioritas dan meremehkan yaitu jika yang menertawakan berada pada posisi super atau pada posisi di atas dan merasa unggul, sedangkan objek yang ditertawai berada pada posisi degradasi, posisi dibawah yang lemah, tertindas, diremehkan, dan dihina.

b) Teori ketidaksesuaian ini adalah bisa dikatakan sebuah teori humor putus harapan, dan bisosiasi yaitu mengemukakan dua situasi atau kejadian yang mustahil terjadi sekaligus. Sesuatu hal yang lucu dan mengundang tawa jika terjadi perubahan dari situasi yang sebelumnya sangat diharapkan.

c) Teori humor kelegaan atau kebebasan ini kalimatnya bernada melepaskan diri dari suatu kekangan-kekangan seseorang dari permasalahan hidup, dan dapat dilampiaskan kepada individu, atau pun pemerintah. Melampiasnya pun lewat humor yang beraneka, seperti politik, ekonomi, sosial, hukum, seks dan sebagainya. Dan gaya lontaran humornya pun berupa gaya satire, yakni sebuah sind iran, umpatan, ataupun hinaan terhapad humor yang dituju.

\section{(2) Jenis Humor}

Menurut Setiawan (dalam Rahmanadji, 2009:217) jenis humor dapat dibedakan menurut kriterium 'bentuk ekspresi”. Seperti bentuk ekspresi dalam kehidupan kita, humor dibagi menjadi tiga jenis sebagai berikut.

a) Humor personal ialah humor yang cenderung tertawa pada diri kita sendiri. Misalnya bila kita melihat sebatang pohon yang bentuknya mirip orang sedang buang air besar. Atau bisa juga melihat sesuatu yang lucu dari orang lain, yang biasanya dalam unsur menertawakan atau mengejek.

b) Humor dalam pergalauan ialah humor yang berada pada situasi perkumpulan antar teman atau dengan sekelompok orang bisa yang berbentuk komunitas. Misalnya senda gurau di antara teman, kelucuan yang diselipkan dalam pidato atau ceramah di depan umum.

c) Humor dalam kesenian atau seni humor masih dibagi, yakni sebagai berikut.
(1) Humor Lakuan
Misalnya: Lawak, tari humor, dan pantonim lucu.
(2) Humor Grafis
Misalnya: Kartun, kari-katur, foto jeneka, dan patung lucu.
(3) Humor Literatur 
Misalnya: cerpen lucu, esei satiris, sajak jenaka, dan sebagainya.

Dalam komunikasi dalam humor terdapat tiga jenis, yakni:

(1) Si penyampai memang bermaksud melucu, dan si penerima menerima sebagai lelucon.

(2) Si penyampai tidak bermaksud melucu, namun si penerima menganggap lucu.

(3) Si penyampai bermaksud melucu, namun si penerima tidak menganggap lucu.

\section{2) Stand Up Comedy}

Stand up comedy adalah salah satu seni dalam melawak, yang pelawaknya membawakan lawakannya di atas panggung seorang diri dengan cara bermonolog, dari hasil pengamatan, pendapat dan pengalaman pribadinya. dan orang yang melakukan kegiatan melawak seorang diri dengan cara bermonolog di atas panggung disebut sebagai pelawak tunggal dan dalam bahasa Inggris yakni stand up comedian. Isi dari lawakan mereka biasanya mengutarakan keresahan, mengangkat kenyataan, memotret kehidupan sosial masyarakat, dan menyuguhkan kembali kepada masyarakat dengan jenaka.

\section{(1) Sejarah Stand Up Comedy}

Stand up comedy awalnya popular di Eropa dan Amerika pada abad ke-18. Dalam sejarahnya perkembangannya juga ditemui di berbagai benua.Terutama di Amerika Serikat sekitar tahun 1800an. Pada saat itu masih berwujud dalam bentuk teater. Teaternya sendiri bernama The Minstrel Show, yang siselenggarakan oleh Thomas Dartmouth "Daddy" Rice.

Pertunujkan stand up comedy ini pada awal pertunjukannya di aula pertunjukan musik. Di Inggris pada tahun 1979 terbentuk sebuah kelompok stand up comedygaya Amerika yang pertama kali didirikan oleh Peter Rosengard. Seiring awal munculnya kelompok stand up comedy di Amerika, kemudian mulai bermunculan kelompok-kelompok stand up comedy di berbagai penjuru dunia termasuk Indonesia.

\section{(2) Sejarah Stand Up Comedy di Indonesia}

Sebenarnya stand up comedy di Indonesia sudah ada sejak lama, pada tahun 90-an. Nama-nama seperti Taufik Savalas, Butet Katardjasa dan Ramon Papana. Tetapi pada saat itu stand up comedy tidak banyak diminati oleh masyarakat Indonesia. Hingga akhir, para kaum baru berusaha untuk menarik penonton dan masyarakat Indonesia untuk mengetahui stand up comedy.

\section{3) Makna}

\section{(1) Pengertian Makna}

Banyak pengertian yang diberikan terhadap makna, tetapi hanya 'arti' yang paling dekat pengertiannya dengan makna.Meskipun demikian, bukan berarti keduannya sinonim mutlak. Disebut demikian karena arti adalah kata yang telah mencangkup makna dan pengertian (menurut Kridalaksana, dalam Aminuddin, 2008: 50)

Menurut Grice, Bolinger (dalam Aminuddin, 2008: 52-53) makna ialah hubungan antara bahasa dengan dunia luar yang telah disepakati bersama oleh para pemakai bahasa sehingga dapat saling dimengerti. Dari batasan pengertian itu dapat diketahui adanya tiga unsur pokok yang tercakup di dalamnya sebagai berikut.

a) Makna adalah hasil hubungan antara bahasa dengan dunia luar

b) Penentuan hubungan terjadi karena kesepakatan para pemakai

c) Perwujudan makna itu dapat digunakan untuk menyampaikan informasi sehingga dapat saling dimengerti. 
Menurut Alston (dalam Aminuddin, 2008: 55) menyebutkan adanya tiga pendekatan dalam teori makna yang masing-masing memiliki dasar pusat pandang berbeda-beda. Yakni meliputi pendekatan (1) referensial, (2) ideasional, (3) behavioral.

\section{(2) Jenis Makna}

(a) Makna Leksikal

Leksikal adalah bentuk adjektif yang diturunkan dari bentuk nomina leksikon (vokabuler, kosa kata, perbendaharaan kata).Satuan dari leksikon adalah leksem, yaitu bentuk bahasa yang bermakna.Kalau leksikon kita samakan dengan kosakata atau perbendaharaan kata, maka leksem dapat dipersamakan dengan kata.Dengan demikian makna leksikal dapat diartikan sebagai makna yang bersifat leksikon, bersifat leksem, atau bersifat kata. Maka makna leksikal adalah makna yang sesuai dengan referennya, makna yang sesuai dengan hasil observasi alat indra, atau makna yang sungguh-sungguh nyata dalam kehidupan kita (Chaer, 2009:60).

(b) Makna Gramatikal

Makna gramatikal adalah makna yang hadir sebagai akibat adanya proses gramatika seperti proses afiksasi, proses reduplikasi, dan proses komposisi (Chaer, 2009: 60).

(c) Makna Referensial

Kata yang mempunyai referen, yaitu sesuatu diluar bahasa yang diacu oleh kata tersebut maka kata itu disebut kata bermakna referensial.

(d) Makna Nonreferensial

Makna nonreferensial adalah kata-kata yang tidak mempunyai referen.Dan yang termasuk pada makan nonreferensial ialah seperti preposisi dan konjungsi.Kata pada makna nonreferensial hanya memiliki fungsi dan tugas dan maka dinamailah kata tersebut dengan naman kata fungsi dan kata tugas.

(e) Makna Denotatif

Setiap kata, terutama yang disebutkan kata penuh, mempunyai makna denotatif, tetapi tidak semua kata itu mempunya makna denotatif. Makna denotatif pada dasarnya sama seperti makna referensial, sebab makna denotative ini lazim diebrikan penjelasan sebagai makna yang sesuai dengan penglihatan, pendengaran, perasaan, penciuman, dan masih banyak lagi. Jadi makna denotatif ini menyangkut kepada informasi-informasi yang faktual dan objektif.

(f) Makna Konotatif

Tidak setiap kata memiliki makna konotatif.Karena makna konotasi makna tambahan yang memiliki sifat sebuah kata disebut makna konotatif apabila kata itu memiliki nilai rasa, baik positif maupun negatif, dan ada juga konotasi netral yang tidak memiliki rasa.

(g) Makna Kata

Ketepatan makna kata dalam penggunaanya secara umum dan secara khusus. Dalam penggunaan bahasa secara umum acapkali kata-kata itu digunakan secara tidak cermat sehingga maknanya bersifat umum.

(h) Makna Istilah

Makna istilah memiliki makna yang tetap dan pasti.Ketetapan dan kepastian makna istilah itu karena istilah itu hanya digunakan dalam bidang kegiatan atau kelimuan tertentu.Jadi, tanpa konteks kalimatnya pun, makna istilah itu sudah pasti.

(i) Makna Konseptual 
Makna konseptual adalah makna yang sesuai dengan konsepnya, makna yang sesuai dengan referennya, dan makna yang bebas dari asosiasi atau hubungan apa pun.

(j) Makna Asosiatif

Makna asosiatif adalah makna yang dimiliki sebuah kata berkenaan dengan adanya hubungan kata itu dengan keadaan di luar bahasa.

(k) Makna Idiomatikal

Idiom adalah satuan-sataun bahasa (kata, frase, maupun kalimat) yang maknanya tidak dapat diramalkan dari makna leksikal unsur-unsurnya, maupun makna gramatikal satuan-satuan tersebut.

(1) Makna Pribahasa

Makna peribahasa merupakan maknanya yang masih bisa diramalkan, berbeda dengan idiom yang maknanya tidak bisa diramalkan.

(m) Makna Kias

Semua bentuk bahasa (baik kata, frase, maupun kalimat) yang tidak merujuk pada arti sebenarnya (arti leksikal, arti konseptual, atau arti denotative) disebut mempunyai arti kiasan.

(n) Makna Lokusi, Ilokusi, dan Perlokusi

Makna lokusi adalah makna seperti yang dinyatakan dalam ujaran, makna harfiah, atau makna apa adanya. Makna ilokusi adalah makna seperti yang dipahami oleh pendengar.Makna perlokusi makna seperti yang diing inkan oleh penutur.

(o) Makna Kontekstual

Makna kontekstual adalah makna sebuah leksem atau kata yang berada dalam konteks.Makna konteks juga dapat berkenaan dengan situasinya yakni tempat, waktu, lingkungan penggunaan leksem tersebut (Chaer, 2008: 72).

\section{METODE PENELITIAN}

Metode penelitian dasarnya merupakan cara ilmiah untuk mendapatkan data dengan tujuan dan kegunaan tertentu. (Sugiyono, 2013:2). Metode yang digunakan dalam penelitian ini adalah deskriptif analitik.Metode deskriptif analitik adalah metode yang menggunakan kedalaman penghayatan terhadap interaksi antarkonsep yang sedang dikaji.

\section{HASIL DAN PEMBAHASAN}

Kalimat humor yang terdapat dalam monolog humor Jui Purwoto ialah ada lima belas kalimat humor. Makna kontekstual disetiap kalimat humor dalam monolog humornya Jui Purwoto terungkap jika kita memahami situasi, kondisi dan peristiwa dimana dan pada situasi apa kalimat itu diucapkan. Karena pada kalimat humor Jui Purwoto ini penulis telah megetahui dimana dan pada situasi apa kalimat humor itu diucapkan, pada saat Jui Purwoto bermonolog humor atau berstand up comedy di depan penonton. Dan setiap kalimat yang diutarakan oleh Jui berkaitan dengan kalimat yang sebelumnya diucapkan.Karena itu penulis memahami makna yang terkandung dalam kalimatnya.Sedangkan makna konseptual yang tidak ada pengaruhnya oleh situasi, kondisi, karena tidak ada pengaruhnya dari diluar kebahasaan. Dan makna konseptual sendiri adalah makna sebenarnya yang sesuai dengan konsep kalimat yang diucapkan oleh Jui Purwoto.

Kalimat humor Jui Purwoto, lebih unggu menggunakan teori ketidaksesuaian atau ketidakseimbangan, dengan membawa pemikiran penonton untuk mengikuti pikirannya, dan di akhir kalimat Jui Purwoto mengejutkan dengan perkiraan yang jauh berbeda dari apa yang sudah dipeikirkan penonton. Inilah puncak tawa penonton dengan plesetannya Jui dalam berstand up comedy. 
Kalimat humor yang terdapat dalam monolog humor Cak Lontong ialah ada sebelas kalimat humor. Makna kontektual disetiap kalimat humornya terungkap setelah kita memahami apa yang diucapkan Cak Lontong dengan adanya pengaruh dari situasi, kondisi, dan peristiwa kalimat tersebut diucapkan. Dan penulis mengetahui kalimat yang diucapkan Cak Lontong ialah pada saat ber stand up comedy dalam situasi yang nyatanya Cak Lontong sedang melakukan humor. Situasi, kondisi, dan peritiwanya pun jelas terlihat dari cuplikan video Cak Lontong yang melakukan stand up comedy di depan penonton. Jadi pemahaman maknanya pun dapat di pahami oleh penulis. Sedangkan pada makna konseptual pada kalimat humor Cak Lontong ialah kalimat yang sudah sesuai dengan konsep kalimatnya, tidak ada pengaruhnya dari luar kebahasaan yakni situasi, kondisi, dan peritiwa. Apa yang diucapkan oleh Cak Lontong yang dijadikannya sebagai kalimat humor maknya pun tetap sama, sesuai konsep kalimatnya tersebut.

Kalimat humor Cak Lontong dilihat dari teori humor menurut Manser ini mengguli pada teori ketidaksesuaia atau ketidakseimbangan. Memang Cak Lontong pandai dalam mangajak penontonya untuk masuk dan mengikuti jalan pikirannya, dengan kepandaiannya ia membelokan dengan mengejutkan munculnya perkiraan kalimat yang tidak diduga oleh penonton yang sebelumnya sudah ikut dalam pikirannya dan memperkirakan apa yang akan disebutkan oleh Cak Lontong.

Kalimat humor yang terdapat dalam monolog humor Pandji Pragiwaksono ialah ada dua belas kalimat humor.Makna kontekstual pada kalimat humornya terungkap jika kita memahami kalimat tersebut dari situasi, kondisi, dan peristiwa dimana kalimat tersebut diucapkan.Karena kalimat yang dilihat dari makna kontekstual sangat berpengaruh dari situasi, kondisi, dan peristiwa sehingga dapat memahami maknanya. Sedangkan makna konseptual pada kalimat humor Pandji, kalimat yang tidak terpengaruh dengan situasi, kondisi, dan peritiwa, karena maknanya sesuai dengan konsep kalimatnya.

Kalimat humor Pandji Pragiwaksono ini lebih unggul dengan menggunakan teori humor kelegaan atau kebebasan. Karena kalimat humornya terdapat ungkapan keprihatinan terhadap keadaan Jakarta dengan sindiran yang dikemas kedalam kalimat humor. Dan juga perihal Sea Games yang menjadi objek materi monolog humor Pandji Pragiwaksono.

Empat belas kalimat humor yang digunakan Ernest Prakasa dalam monolog humornya.Makna kontekstual disetiap kalimat humornya penulis memahami.Karena kalimat yang dilihat dari makna kontekstual sangat berpengaruh pada situasi, kondisi, dan peristiwa. Dan pada kalimat humor Ernest ini penulis memahami apa isa dalam monolog humornya, dan mengetahui situasi saat Ernest berstand up comedy dalam video.sedangkan makna konseptual, ialah makna yang tidak ada pengaruhnya terhadap diluar kebahasaan, situasi, kondisi, dan peristiwa. Makna yang dilihat dari konsep kalimatnya.

Kaliamt humor Ernest Prakasa dilihat menurut teori humor Manser, ia lebih unggul dengan teori ketidaksesuaia atau ketidakseimbngan, dengan mengajak penonton untuk berpikir tentang apa yang sedang diungkapkan oleh dirinya, dan hingga akhirnya ia merubah pikirannya dengan suatu hal diluar perkiraan penonton, dan disnilah yang menjadikan humor lebih mengajak kita untuk berpikir, bukan sekedar tertawa tetapi tidak memahaminya.

\section{SIMPULAN}

Berdasarkan analisis yang telah dilakukan, maka penulis menyimpulkan hal-hal sebagai berikut.

1) Kalimat humor Jui Purwoto pada penampilannya di stand up comedy terdapat pada monolog humornya. Yang telah dianalisis pada sudut pandang makna kontekstual, makna konseptual, dan teori humor. Dan menceritakan tentang kejadian pembunuhan gadis belia oleh mantan kekasihnya hingga ramainya tauran yang berawal dari tidak adanya kegiatan setalah pulang sekolah.

2) Makna kontekstual, makna konseptual dan teori humor dalam kalimat humor yang digunakan Jui Purwoto pada penampilannya di stand up comedy adalah kalimat 
humor yang dilihat pada makna kontekstual sangat berpengaruh terhadap situasi, kondisi, dan peristiwa dimana kalimat humor terucap. Pada kalimat humor Jui ini yang didalamnya tentang pembunuhan gadis belia oleh mantan kekasihnya sampai permasalahan tentang tauran yang sering terjadi. Kalimat humor Jui Purwoto yang dilihat pada makna konseptual ini tidak perlu adanya pengaruh diluar bahasa, situasi, kondisi, dan peristiwa. Tanpa mengetahui situasi, kondisi, dan peritiwa, kita dapat memahami makna yang terkandung, karena maknanya sudah terlihat pada konsep kalimatnya.Teori humor pada kalimat humor Jui Purwoto lebih banyak menggunakan teori ketidaksesuaian atau ketidakseimbangan. Selanjutnya teori kelegaan atau kebebasan, dan teori superioritas dan meremehkan.

3) Kalimat humor Cak Lontong pada penampilannya di stand up comedy terdapat pada monolog humornya yang menceritakan tentang miskin dan sederhana menurut Cak Lontong.

4) Makna kontekstual, makna konseptual dan teori humor dalam kalimat humor Cak Lontong pada penampilannya di stand up comedy adalah kalimat humor yang dilihat ada makna kontekstual ini sangat dipengaruhi oleh situasi, kondisi, dan peristiwa pada saat kalimat humor diucapkan oleh Cak Lontong. Dan kalimat ini diucapkan pada saat Cak melakukan stand up comedyyang didalamnya menceritakan tentang miskin dan sederhana. Sedangkan pada kalimat humor Cak Lontong yang dilihat pada makna konseptual tidak ada pengaruhnya oleh situasi, kondisi, dan peristiwa. Sebagai pembaca tanpa mengetahui pengaruh luar kebahasaan tetap akan memahami makna kalimat tersebut sesuai konsep kalimatnya. Dan pada teori humor dalam kalimat humor Cak lontong yang lebih unggul digunakannya adalah teori ketidaksesuaia, atau ketidakseimbangan.

5) Kalimat humor Pandji Pragiwaksono pada penampilannya di stand up comedy terdapat pada monolog humornya yang berisikan tentang Sea Games, dan kemenangan Indonesia dalam ajang Sea Games, serta adanya umpatan Pandji tentang Jakarta yang nyatanya terdapat kemunduruan.

6) Makna kontekstual, makna konseptual dan teori humor dalam kalimat humor Pandji Pragiwaksono pada penampilannya di stand up comedy adalah kalimat yang dianalisis pada makna kontekstual sangat berpengaruh terhadap luar kebahasaan yakni situasi, kondisi, dan peristiwa diman akalimat tersebut diucapkan. Danpada kalimat humor Pandji yang diucapkan saat penampilannya berstand up comedy di depan penonton yang menceritakan kedalam bentuk humor. Dan pada makna konseptual kalimat dapat dipahami tanpa adanya pengaruh dari situasi, kondisi, dan peristiwa. Kalimat humor pada teori humor yang digunakan Pandji lebih unggul dengan teori kelegaan dan kebebasan karena dalam kalimat humornya banyak sindiran dan umpatan yang dikeluarkan Pnadji dengan cara berhumornya.

7) Kalimat humor Ernesr Prakasa pada penampilannya di stand up comedy terdapat pada monolog humor Ernest Prakasa yang berisikan tentang cerita saat dirinya membeli televisi, dan kisah tentang pembantu rumah tangganya yang memliki bahasa yang aneh.

8) Makna kontekstual, makna konseptual dan teori humor dalam kalimat humor Ernest Prakasa pada penampilannya di stand up comedy adalah kalimat humor yang dianalisis pada makna kontekstual sangat berpengaruh terhadap situasi, kondisi, dan peritiwa dimana kalimat humor tersebut di ucapkan oleh Ernest. Dan pada saat itu, kalimat diucapkan pada saat Ernest berstand up comedy yang menceritakan tentang pengalamannya membeli televisi dan menceritakan pula pembantunya yang memiliki keunikan dalam berbahasa. Sedangkan pada makna konseptual, hanya dilihat dari konsep kalimat humornya itu sendiri, dan maknanya tidak akan berpengaruh dari 
situasi, kondisi, dan peristiwa. Dan kalimat humor Ernest yang lebih unggul dalam teori humor yang digunakan adalah teori ketidaksesuaia atau ketidakseimbangan.

\section{DAFTAR PUSTAKA}

Aminuddin.(2008). Semantik Pengantar Studi Tentang Makna.Bandung : Sinar Baru Algensindo.

Bastian, Radis.(2014). Salam Lemper Cak Lontong Di Balik "Survei-Survei" Lemper yang Bikin Darah Tinggi.Jogjakarta : Flashbooks.

Chaer, Abdul. (2009). Pengantar Semantik Bahasa Indonesia. Jakarta: Penerbit Rineka Cipta.

Chaer, Abdul. (2008). Linguistik Umum. Jakarta: Rineka Cipta.

Heryadi, Dedi. (2010). Metode Penelitian Pendidikan Bahasa.Bandung : Pustaka Billah.

Keraf, Gorys. (2010). Diksi dan Gaya Bahasa.Jakarta : Gramedia Pustaka Umum.

Pragiwaksono, Pandji. (2012). Merdeka Dalam Bercanda. Yogyakarta : Bentang.

Rahmanadji, Didiek. (2003). Sejarah, Teori, Jenis, dan Fungsi Humor. Malang: Universitas Negeri Malang. (online) Tersedia: sastra.um.ac.id/wpcontent/uploads/2009/10/Sejarah-Teori-Jenis-dan-Fungsi-Humor.pdf.

Sugiantomas, Aan. (2012). Kajian Prosa Fiksi dan Drama.Kuningan : Program Studi Pendidikan Bahasa dan Sastra Indonesia Universitas Kuningan.

Sugiyono. (2013). Metode Penelitian Kuantitatif Kualitatif dan R\&D. Bandung : Penerbit Alfa Beta.

Tarigan, Henry Guntur. (1985). Pengajaran Gaya Bahasa.Bandung : Angkasa.

Wikipedia.Lawak. (online) Tersedia: id.wikipedia.org/wiki/lawak

Wikipedia.Pelawak Tunggal. Tersedia: id.wikipedia.org/wiki/Pelawak_Tunggal. 